\title{
Research on the Website Construction of Shanghai A-Level Tourist Attractions Based on eMICA Model
}

\author{
Kaibo Zhou, Xiaobo Jia \\ Shanghai Normal University Tianhua College \\ Shanghai, 201815, China
}

\begin{abstract}
This paper uses Extended Model of Internet Commerce Adoption (eMICA model) to analyze the website construction of e-commerce of Shanghai A-level tourist attractions. In the light of eMICA model, this paper divides these websites into different stages in order to find out problems such as slow information update, poor interaction, lack of ability in handling with transaction, etc. in the process of website construction of Shanghai A-level tourist attractions and propose corresponding measures, which may be helpful to provide reference for the website construction of A-level tourist attractions.
\end{abstract}

\section{Keywords-eMICA, Shanghai, tourist attractions, website}

Internet has become the best medium for the marketing of tourist attractions. Shanghai A-level tourist attractions have also set up their own official websites. However, there are plights in these websites such as few websites visitors, low purchase rate and more tourists buying tickets from the third party platforms. Therefore, this paper use eMICA model to study the website construction of Shanghai A-level tourist attractions and analyze its development and problems in order to provide reference for tourist attractions.

\section{INTRODUCTION}

\section{A. Shanghai A-level tourist attractions}

"Tourist attraction refers to an independent administrative district which not only has such functions as sightseeing, relaxation and vacation and recreation and fitness, but also is equipped with related tourist service facilities and provides relevant tourist service."[1]

The source of Shanghai A-level tourist attractions used in this paper is from the list of A-level tourist attractions in the official website of Shanghai municipal tourism administration, among which there are 3 national 5A tourist attractions, 52 national $4 \mathrm{~A}$ tourist attractions and 46 national 3A tourist attractions, totaling 101 A-level tourist attractions.[2] This paper will take 73 national A-level tourist attractions as its research objects excluding 8 national $4 \mathrm{~A}$ tourist attractions and 20 national 3A s tourist attractions which have not official websites.

\section{B. The website of tourism e-commerce}

"Tourism e-commerce is the application of e-commerce in the specific industry of tourism, which electronizes each part of commercial activities by means of the technology of modern network information."[3] The website of tourism e-commerce is the network platform in which tourist attractions conduct ecommerce activities through the technology of network information.

\section{C. eMICA model}

Extended Model of Internet Commerce Adoption, short for eMICA model, is the extended model of the application of Internet commerce, which is firstly proposed by Burgess L and Cooper $\mathrm{J}$ in 2000 who applied it in tourist websites in 145 regions in Australia.[4] Then in 2002, Burgess L and Cooper J, together with Doolin B, used eMICA model again to evaluate the website construction of tourism organizations in 26 regions in New Zealand and compared its result with the one in Australia, finding that the results of these two studies were highly consistent. Thus, eMICA has high maturity and effectiveness in evaluating tourism websites.[5]

TABLE I. THE EXTENDED MODEL OF INTERNET COMMERCE ADOPTION(EMICA);ADAPTED FROM BURGESS AND COOPER(2000) [A]

\begin{tabular}{l|l}
\hline EMICA & Examples of functionality \\
\hline Stage1-promotion & $\begin{array}{l}\text { Company name, physical address and contact } \\
\text { details, area of business }\end{array}$ \\
\hline $\begin{array}{l}\text { Layer1-basic } \\
\text { information }\end{array}$ & $\begin{array}{l}\text { Annual report, email contact, information on } \\
\text { company activities }\end{array}$ \\
\hline $\begin{array}{l}\text { Layer2-rich } \\
\text { information }\end{array}$ & $\begin{array}{l}\text { Basic product catalogue, hyperlinks to further } \\
\text { information, online enquiry form }\end{array}$ \\
\hline Stage2-Provision & $\begin{array}{l}\text { Higher-level product catalogues, customer } \\
\text { support (e.g.,FAQs, sitemaps),industry-specific } \\
\text { value-added features }\end{array}$ \\
\hline $\begin{array}{l}\text { Layer1-low } \\
\text { interactivity }\end{array}$ & $\begin{array}{l}\text { Chat room, discussion forum, multimedia, } \\
\text { newsletters by email }\end{array}$ \\
\hline $\begin{array}{l}\text { Layer2-medium } \\
\text { interactivity }\end{array}$ & $\begin{array}{l}\text { Secure online transactions, order status and } \\
\text { tracking, interaction with corporate servers }\end{array}$ \\
\hline $\begin{array}{l}\text { Layer1-high } \\
\text { interactivity }\end{array}$ &
\end{tabular}

According to the characteristics of the websites of Shanghai A-level tourist attractions, the author revises eMICA model and then uses it in the evaluation of website construction of Shanghai A-level tourist attractions.

\section{QUESTIONNAIRE SURVEY}

\section{A. The design and delivery of questionnaire}

The questionnaire on the website construction of Shanghai A-level tourist attractions is based on key functional design of 
eMICA model. In the part of information necessity of Shanghai A-level tourist attractions in questionnaire, interviewees evaluate the contents of the websites of Shanghai A-level tourist attractions in accordance with Likert scale. The degree of information importance ranks 5 level, rating from 1 to 5 , that is extremely important, relatively important, important, less important and unimportant. The whole content of questionnaire has close relation with eMICA model, investigating tourists, visits to the websites of tourist attractions and importance degree of website information and analyzing tourists' knowledge about websites of tourist attractions and the information provided by websites that need to be improved.
The author delivers 600 questionnaires in the platform of questionnaire star and adopts stratified sampling to investigate while taking the Internet users who set Shanghai IP address as the subjects of questionnaire. There are 561 valid questionnaires and 39 invalid questionnaires which are excluded.

\section{B. The result of questionnaire}

The author draws the conclusions as shown in TABLE II by adopting SPSS19 to tally the frequency of data and analyze crosstab and average value.

TABLE II. ANALYTICAL ST ATEMENT OF INFORMATION NECESSITY OF THE WEBSITES OF A-LEVEL TOURIST ATTRACTIONS IN SHANGHAI

\begin{tabular}{|c|c|c|c|c|}
\hline $\begin{array}{l}\text { Serial } \\
\text { No. }\end{array}$ & Item & $\begin{array}{l}\text { Avg. } \\
\text { Value }\end{array}$ & $\begin{array}{l}\text { Standard } \\
\text { deviation }\end{array}$ & $\begin{array}{c}\text { Standard } \\
\text { error }\end{array}$ \\
\hline 1 & Basic information of tourist attractions (address, e-mail, telephone, etc.) & 1.904 & 0.619 & 0.030 \\
\hline 2 & Pictures of tourist attractions & 1.913 & 0.514 & 0.021 \\
\hline 3 & Profile of tourist attractions & 1.846 & 0.545 & 0.023 \\
\hline 4 & Value-added information of diversity (news, map, tourist rout, traffic information, etc.) & 1.856 & 0.529 & 0.021 \\
\hline 5 & Accommodation information & 2.135 & 0.614 & 0.031 \\
\hline 6 & Information of festival activities & 2.183 & 0.548 & 0.023 \\
\hline 7 & Discussion board of tourists & 2.192 & 0.582 & 0.027 \\
\hline 8 & Online customer service support & 1.962 & 0.580 & 0.026 \\
\hline 9 & $\begin{array}{l}\text { Tourist information base (which can search accommodation, tourism attraction, food, activities, } \\
\text { shopping, etc.) }\end{array}$ & 1.865 & 0.571 & 0.025 \\
\hline 10 & Online booking for accommodation, sightseeing, transportation & 1.990 & 0.670 & 0.035 \\
\hline 11 & Senior value-added service( plurilingual support, e-mail notice) & 2.231 & 0.595 & 0.028 \\
\hline 12 & Safe online payment & 1.760 & 0.476 & 0.022 \\
\hline
\end{tabular}

According to the data in TABLE II, tourists attach great importance to "safe online payment" with average value of 1.760, far higher than other items, which indicates that tourists have high demand for online tickets and have high expectation of safety factor of pattern of payment. With regard to 3 functions in the first stage of eMICA model, compared with basic information and pictures, tourists attach more importance to "the profile of tourist attraction" with average value of 1.846. Thus, in this model, it should emphasize the description of characteristics in the first stage. As for the functions in the second stage, the average value of "value-added information of diversity" is 1.856 and "tourism information base" 1.865 , both of which are important for tourists. And the average values of accommodation, activities, events information and discussion board of tourists are above 2.1, which shows that tourists have low demand for these aspects and it should adjust their positions in the model. In the key function of the third stage, the demand for "online reservation of accommodation, sightseeing and transportation" is significantly higher than other senior value-added services, thus it should exchange their position in functional layering.

To sum up, key functions in each stage listed by eMICA model are highly consistent with the needs of tourists for the websites of tourist attractions, which once again verifies the authority and effectiveness of this model in the field of evaluation and research of website construction of tourist attractions.
In TABLE II, the standard deviation of data in each item is relatively low, indicating that the attention paid by tourists to the information provided by the websites of tourist attractions is close to each average value. Standard error of each data is relatively low, which shows that deviation between statistical data of samples and actual data is small, having high accuracy.

\section{Evaluation model of the websites of A-level tourist attractions in Shanghai}

According to the result of the questionnaire, the author adjusts the functional layering of original eMICA model in order to change the sequence of demand in the light of demand index of tourists on each function in the same stage and obtain the ultimate research model suitable for the study of the websites of A-level tourist attractions in Shanghai. (As shown in TABLE III) 
TABLE III. THE EXTENDED MODEL OF INTERNET COMMERCE ADOPTION(EMICA) OF A-LEVEL TOURIST ATTRACTIONS IN SHANGHAI

\begin{tabular}{|c|c|}
\hline Stage & functionality \\
\hline \multirow{3}{*}{ Stage1 } & 1.email contact details \\
\hline & 2.Images \\
\hline & 3.description of tourism features \\
\hline \multirow{4}{*}{$\begin{array}{l}\text { Stage2 } \\
\text { /Layer1 }\end{array}$} & 4.systematic links to further information \\
\hline & 5.lists of accommodation, attractions, activities, events with contact details and/or links \\
\hline & 6.Web-based inquiry or order form \\
\hline & 7.multiple value-added features(news, maps, tourist routes, traffic information) \\
\hline \multirow{3}{*}{$\begin{array}{l}\text { Stage2 } \\
\text { /Layer2 }\end{array}$} & $\begin{array}{l}\text { 8.interactive value-added features(currency converters, electronic postcards, interactive maps, download-able materials, special offers, guest books, } \\
\text { Web cam) }\end{array}$ \\
\hline & 9.online customer support(FAQs, site map, site search engine) \\
\hline & 10.searchable databases for accommodation, attractions, activities, dining, shopping, events \\
\hline \multirow{3}{*}{$\begin{array}{l}\text { Stage2 } \\
\text { /Layer3 }\end{array}$} & 11.advanced value-added features(multi-Language support, multimedia, email updates) \\
\hline & 12.online bookings for accommodation, tours, travel \\
\hline & 13.non-secure online payment \\
\hline Stage3 & 14.secure online payment \\
\hline
\end{tabular}

D. The evaluation result of the websites of A-level tourist attractions in Shanghai

According to the survey conducted between October 2016 and July 2018, the author includes 73 websites of A-level tourist attractions in Shanghai into corresponding stages and layers in accordance with their current development level. The result is as shown in TABLE IV.

TABLE IV. EVALUATION RESULT OF WEBSITES OF A-LEVEL TOURIST ATTRACT IONS IN SHANGHAI

\begin{tabular}{|c|c|c|c|c|}
\hline Stages in eMICA model & $\begin{array}{c}\text { 5A tourist } \\
\text { attractions }\end{array}$ & $\begin{array}{c}\text { 4A tourist } \\
\text { attractions }\end{array}$ & $\begin{array}{c}\text { 3A tourist } \\
\text { attractions }\end{array}$ & $\begin{array}{c}\text { Total } \\
\text { No. }\end{array}$ \\
\hline Stage 1 & 0 & 6 & 2 & 8 \\
\hline Stage 2/layer 1 & 1 & 13 & 18 & 32 \\
\hline Stage 2/layer 2 & 0 & 12 & 3 & 15 \\
\hline Stage 2/layer 3 & 0 & 2 & 1 & 3 \\
\hline Stage 3 & 2 & 12 & 1 & 15 \\
\hline Total No. & 3 & 45 & 25 & 73 \\
\hline \multicolumn{7}{|r}{}
\end{tabular}

As shown in TABLE IV, the overall situation of website construction of A-level tourist attractions in Shanghai currently performs well. Among 73 websites of A-level tourist attractions, there are 8 tourist attractions in the first stage in eMICA model, 50 in the second stage and 15 in the third stage, highest stage in eMICA model, which meets the needs of safe online payment.

Among 3 national 5A tourist attractions, 2 tourist attractions have reached the third stage in the eMICA model with well-performed construction situation. But due to lack of practical information in its official website, the tourist attraction of Oriental Pearl Tower is still in the first layer of the second stage in eMICA model.

Among 45 national 4A tourist attractions, the websites construction of 12 tourist attractions have reached the third stage in eMICA model, but there are still 6 tourist attractions in the first stage with only few information and pictures.
Among 25 national 3A tourist attractions, 18 tourist attractions are in the first layer of the second stage in this model. The website of Jinshanzui village is the only tourist attraction in the third stage, which indicates that national 3A tourist attractions generally pay little attention to websites.

III. THE PROBLEMS OF THE WEBSITE CONSTRUCTION FOR ALEVEL TOURIST ATTRACTIONS IN SHANGHAI

\section{A. Relatively slow information update}

The author finds from the survey that the update of information in websites of A-level tourist attractions in Shanghai is slow with low update frequency. Most websites update their information in months or even years ago, which is of limited help for tourists to know the latest situation of tourist attractions and to arrange their travel plans.

\section{B. Low interactivity of websites}

"The interactivity of websites can be reflected in multiple aspects, one of which "The interactivity of websites can be reflected in multiple aspects, one of which is to establish complete database for users' retrieval and the other of which is to emphasize the mutual communication between websites and users, give play to the advantages of Internet media and realize mutual interaction."[6] In these two aspects, A-level tourist attractions in Shanghai remain to improve. With regards to information base, there doesn't exist such an information base as includes accommodation, activities, catering, shopping and events with retrieval function. As for mutual communication, 37 websites of tourist attractions only provide some static information and services without interactive function. The function of leaving online messages is launched partly in 36 websites but there is no fixed board for communication. Thus tourists can only leave their telephone number and e-mail to wait for response. Some questions are not answered for even several months.

\section{Lack of value-added function and online users support}

In this questionnaire, the author finds that most tourists mention the problem of value-added function and online users 
support of websites. First of all, the operators of websites do not take the construction of value-added function into consideration. Only 5 websites provide Chinese and English service and 73 websites of national A-level tourist attractions do not have the function to notice the update of e-mail. Secondly, most online users support is limited to e-mail delivery. Only 7 websites have QQ online consultation and there is no website having the function of real-time consultation in platforms.

\section{Lack of the ability to handle with transaction}

In 73 websites of A-level tourist attractions in Shanghai, only 15 websites have the online payment function, among which 14 websites support Alipay and 1 website supports Unionpay. Most tourist attractions such as Shanghai wild animal park, Shanghai happy valley, etc. adopt the function of registered online transaction. Such websites of tourist attractions as Zhujiajiao ancient town and Changfeng ocean world adopt the transaction pattern through verification of cell phones. And Shanghai museum of glass and Chenshan botanical garden require tourists to write information to pay. Generally speaking, only $20 \%$ websites of A-level tourist attractions in Shanghai have the online payment function, which is relatively low proportion.

IV. MEASURES TO OPTIMIZE THE CONSTRUCTION OF ECOMMERCE OF A-LEVEL TOURIST ATTRACTIONS IN SHANGHAI

\section{A. It should normalize and systematize information update of the websites of tourist attractions}

Tourists wish to obtain and grasp all information about tourist attractions favorable to their own travel arrangement in a timely and systematical way. The information management of the websites of A-level tourist attractions in Shanghai can be developed through the following ways: firstly, permanent staff should be assigned to maintain websites, timely update daily activities of tourist attractions write news about tourist attraction in a regular basis or adopt advertorial to do the marketing. Secondly, it should put news and real-time notice into the homepage of websites and highlight them in a conspicuous manner accompanied by some pictures and videos of activities to enhance the enjoyment of news and thus attract visitors. Thirdly, in large-scale Internet research engines, it should push delivery of major activities and news in order to increase the page view of websites.

\section{B. It should strengthen the interactivity of information service for the websites of tourist attractions}

There are three feasible plans for the websites of A-level tourist attractions in Shanghai to enhance interactivity. The first one is to adjust page layout, establish specific message board or forum of tourist attractions and assign specific person to maintain and manage websites and communicate with tourists, which can solve their problems in a short time. The second one is to build up detailed information base for websites. It should have such a website as is equipped with a database of accommodation surrounding the tourist attractions, specialty catering, activities, local specialties and other tourism attractions, which can significantly increase visit stickiness of tourists. The third one is to create WeChat official account for tourist attractions, enclose QR code in the homepage of websites, update daily news in this account and interact with visitors by the means of delivering advertisement and giving coupon.

\section{It should enhance senior value-added service and online support}

At present, there are only 5 websites offering English version websites and 3 offering Japanese version websites among 73 websites of tourist attractions. It is very inconvenient for foreign tourists to visit the websites of Shanghai tourist attractions. Therefore, it should add English, Japanese and Korean versions to those websites of hottest A-level tourist attractions in Shanghai which have the largest number of foreign visitors, thus serving international visitors and enhancing the image of tourist attractions. The author suggests that the websites of tourist attractions should adopt online consultation in platforms and answer tourists' questions timely. And the update and delivery function of e-mail in the model can totally be replaced by WeChat delivery. Tourist attractions can also strengthen the support service in cell phones and keep close track of the times to adjust the development direction of websites.

\section{It should fortify the function of safe online reservation and payment}

Tourists attach most importance to the function of safe online payment for the websites of tourist attractions. Therefore, it should firstly take the safety of payment into consideration. It can cooperate with large domestic network companies or banks develop the function of online payment through safer ways such as Alipay, WeChat and Unionpay and carefully check the authenticity of order information in order to avoid malicious order. In the meantime, tourists can enjoy discounts by buying tickets in official websites of tourist attractions such as $50 \%$ discount for holiday tickets. By doing so, it can advertise tourist attractions and increase their popularity while attracting tourists.

\section{CONCLUSION}

By taking e-commerce website of A-level tourist attractions in Shanghai as its research object, this paper combines eMICA model and adopts the methods of literature review, questionnaire and statistical analysis to study the construction of e-commerce website of A-level tourist attractions in Shanghai, analyze its development and problems and propose relevant measures from the following four aspects: strengthening the effectiveness of information, enhancing the interactivity of websites, promoting value-added service and increasing the safety of online payment, which might be helpful for the construction of e-commerce websites of tourist attractions. There is considerable room to study the website construction of A-level tourist attractions in Shanghai. Although some research attempts have been made in this paper, the research is not comprehensive and thorough with only providing some superficial opinions for reference and it still requires us to conduct further researches and supplement in the future. 


\section{REFERENCES}

[1] GB/T 17775-2003, On Classification and Evaluation of Quality Grade of Tourist Attractions[S]. General Administration of Quality Supervision, Inspection and Quarantine of the People's Republic of China. 2003. (In Chinese)

[2] A-Level Tourist Attractions. The Official Website of Shanghai Municipal Touris m Administration [EB/OL].http://lyw.sh.gov.cn/201804-16. (In Chinese)
[3] Yu Yang, Touris m E-Commerce[M]. Beijing: Tourism Education Press, 2015:13. (In Chinese)

[4] Cooper J, Burgess L. A model of Internet commerce adoption (MICA)[M] Electronic commerce. IGI Publishing, 2000:189-201.

[5] Doolin B, Burgess L, Cooper J. Evaluating the use of the Web for tourism marketing: a case study from New Zealand[J].Tourism management, 2002, 23(5):557-561.

[6] Zhu Guanmei, Research on the Interactivity of Online Marketing of Travel Agency[D]. Shangdong University, 2008. (In Chinese) 